\title{
Seminal polyamines as agents of cervical carcinoma: Production of aneuploidy in squamous epithelium
}

\author{
S Fletcher, W A Neill, M Norval
}

\begin{abstract}
The effects of several polyamines found in seminal fluid on the cell cycle and ploidy of three cervical cell lines and of primary epithelial cells cultured from cervical biopsy specimens were monitored by fluorescent flow cytometry. The rate of cell growth did not change but there were indications of either hypodiploidy or hyperdiploidy in some cultures at certain concentrations of spermine and spermidine. An interaction of exogenous polyamines with the DNA of cervical cells was shown to occur, leading to changes in ploidy with, perhaps, the potential to induce or promote dysplasia.
\end{abstract}

The cause of cervical squamous carcinoma is unlikely to be unique and may contain components which are both intrinsic and extrinsic to the cervix. The pubertal metamorphosis of the cervix provides the best known intrinsic component-the ectopy of columnar glandular epithelium with the emergence of a new type of squamous epithelium. ${ }^{1}$ The squamous replacement arises focally in the columnar and glandular ectopy by basal reserve cell proliferation and creates the transformation zone which is significantly prone to future malignancy. ${ }^{2}$ Malignancy in the transformational squamous epithelium, however, cannot be explained entirely by an intrinsic epithelial instability, and epidemiological and other evidence indicate that extrinsic events play a part. The epidemiological findings favour an agent transmitted sexually from male to female but are unable to specify its exact nature. ${ }^{3}$ Human papillomavirus (HPV) types, in particular, have been much studied and have established interesting and useful correlations with cervical neoplasia, but without defining a causal role. ${ }^{4}$ Less attention, however, has been paid to the possibility of transferable chemical agents acting either as carcinogens or as adjuvants to other agents.

The known growth promoting activities of plant and animal polyamines make them possible candidates. ${ }^{5}$ Seminal fluid contains several polyamines, particularly spermine, in concentrations $(0.5-3.5 \mathrm{mg} / \mathrm{ml})$ exceeding those used in demonstrating their effects in vitro. $^{6}$ Polyamines are essential for cell growth, and raised concentrations of them and their limiting synthetic enzyme, ornithine decarboxylase, which produces the parent molecule putrescine, accompany periods of enhanced growth and differentiation in embryos and of regeneration in rat liver. ${ }^{7}$ The specific inhibitor of ornithine decarboxylase, 2-difluoromethyl ornithine, lowers polyamine concentrations and inhibits cell growth in vivo in animal tumours ${ }^{8}$ and in cell cultures of malignant cell type. ${ }^{9}$ The stimulation of cell growth and especially the prospect of an exogenous activation encouraged us to study the effects of the polyamines found in seminal fluid on cultured cervical squamous epithelium from the transitional zone and also on certain laboratory cell lines.

\section{Methods}

POLYAMINES

Spermine, spermidine, and 1,3-propanediamine were purchased from Sigma (Poole, Dorset). They were dissolved in $0.1 \mathrm{~N} \mathrm{HCl}$ at a concentration of $1 \mathrm{mg}$ per $\mathrm{ml}$ and diluted appropriately in medium just before use.

\section{CELL LINES}

$\mathrm{SiHa}$ and CaSki cell lines were obtained from Dr H Cubie, and HeLa and Vero from Gibco Ltd (Paisley, Scotland). They were cultured as monolayers in Eagle's medium supplemented with $2 \mathrm{mM} \mathrm{L}$-glutamine, $100 \mathrm{IU} / \mathrm{ml}$ penicillin, $200 \mu \mathrm{g} / \mathrm{ml}$ streptomycin and $5 \%$ pooled inactivated human serum. After trypsinisation the cells were subcultured into wells of tissue culture plates (Sterilin UK), $2 \mathrm{ml}$ containing $1 \times 10^{5}$ cells per $\mathrm{ml}$ in each well. The plates were incubated at $37^{\circ} \mathrm{C}$ in $5 \%$ carbon dioxide in air, and one day later polyamines at various concentrations were added for up to 72 hours. Control cultures contained no polyamines.

\section{CERVICAL CELL CULTURES}

Cervical epithelium for culture came from normal (hysterectomy) cervices within $30 \mathrm{~min}$ utes of removal from women between the ages of 27 and 50 years (mean $=41$ years). Under the dissecting microscope the transformation zone was identified and the ring of predominantly squamous epithelium was incised around its inner and outer borders. Anterior and posterior sectors were then defined by two lateral radial incisions. The sectors were lifted by forceps and undercut by fine scissors as closely as possible to the epithelium. Samples for histological examination were taken to confirm their origin and absence of cervical intraepithelial neoplasia, HPV infection, or other abnor- 
Figure 1 DNA

histograms of $\mathrm{SiHa}$

cultures after 48 hours of

incubation: $(A)$ control

cells showing normal $G_{o} / G$

and its corresponding $G_{2} M$

peak; (B) with $0.4 \mu \mathrm{g} / \mathrm{ml}$

spermidine showing an An (aneuploid) peak at aneuploid $G_{0} / G$, with $a$ $D N A$ index of 0.77 and $a$ corresponding aneuploid $G_{2} M$ peak with a DNA index of 1.55 ; (C) with $6 \mu \mathrm{g} / \mathrm{ml}$ spermidine showing aneuploid peaks with DNA indices of 0.78 and 1.65 ; (D) with $12 \mu \mathrm{g} /$ ml spermidine showing aneuploid peaks with DNA indices of 0.76 and 1.60 .

Figure $2 D N A$ histograms of $\mathrm{HeLa}$ cultures after incubation for 48 hours: $(A)$ control cells; $(B)$ with $6 \mu \mathrm{g} / \mathrm{ml}$ spermidine; $(C)$ with

$12 \mu g / m l$ spermidine; $(D)$ with $25 \mu \mathrm{g} / \mathrm{ml}$ spermidine showing a hyperdiploid peak at $A n G_{0} G$ with $D N A$ index of 1.23 and $a$ corresponding GM peak with a DNA index of $2 \cdot 28$.

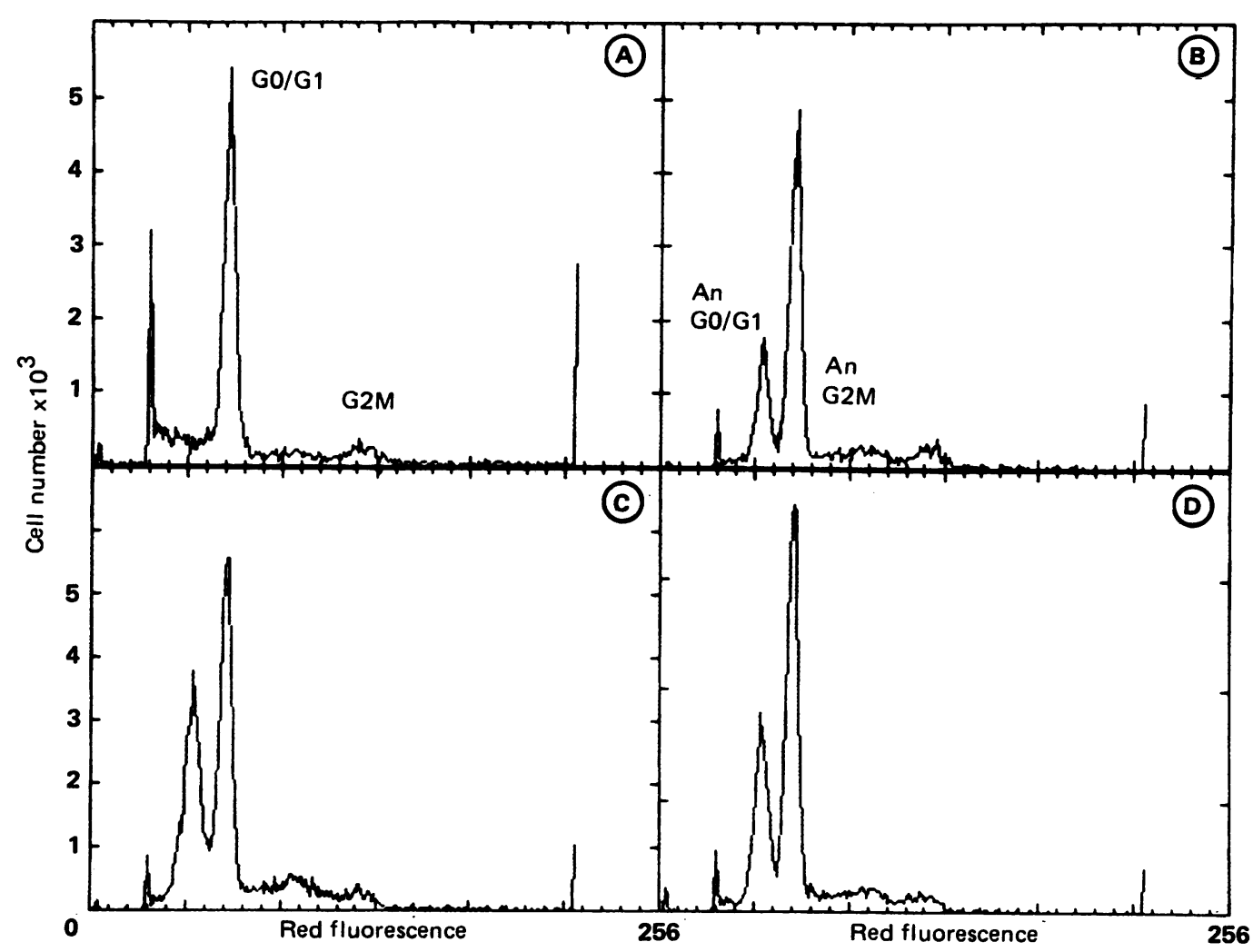

malities. The specimens were minced finely with scissors and four to six pieces were grown in wells of tissue culture plates (Sterilin UK) under cover slips until epithelial outgrowth was established, usually in two to three weeks. The medium was RPMI 1640 containing the same supplements as Eagle's medium above, and it was changed weekly. Cultures were then incubated for a further six days in the same medium but with the addition of polyamines at various concentrations. Control cultures contained no polyamines.
Pooled human serum was used in the culture medium throughout the study to avoid the action of amine oxidase. The enzyme is present in bovine serum, even after inactivation at $56^{\circ} \mathrm{C}$ for 30 minutes, and converts spermine and spermidine to cytotoxic aldehydic products. $^{10}$

DNA ANALYSIS

At the end of the incubation period cultures were harvested by trypsinisation and further processed for DNA analysis by flow cytometry

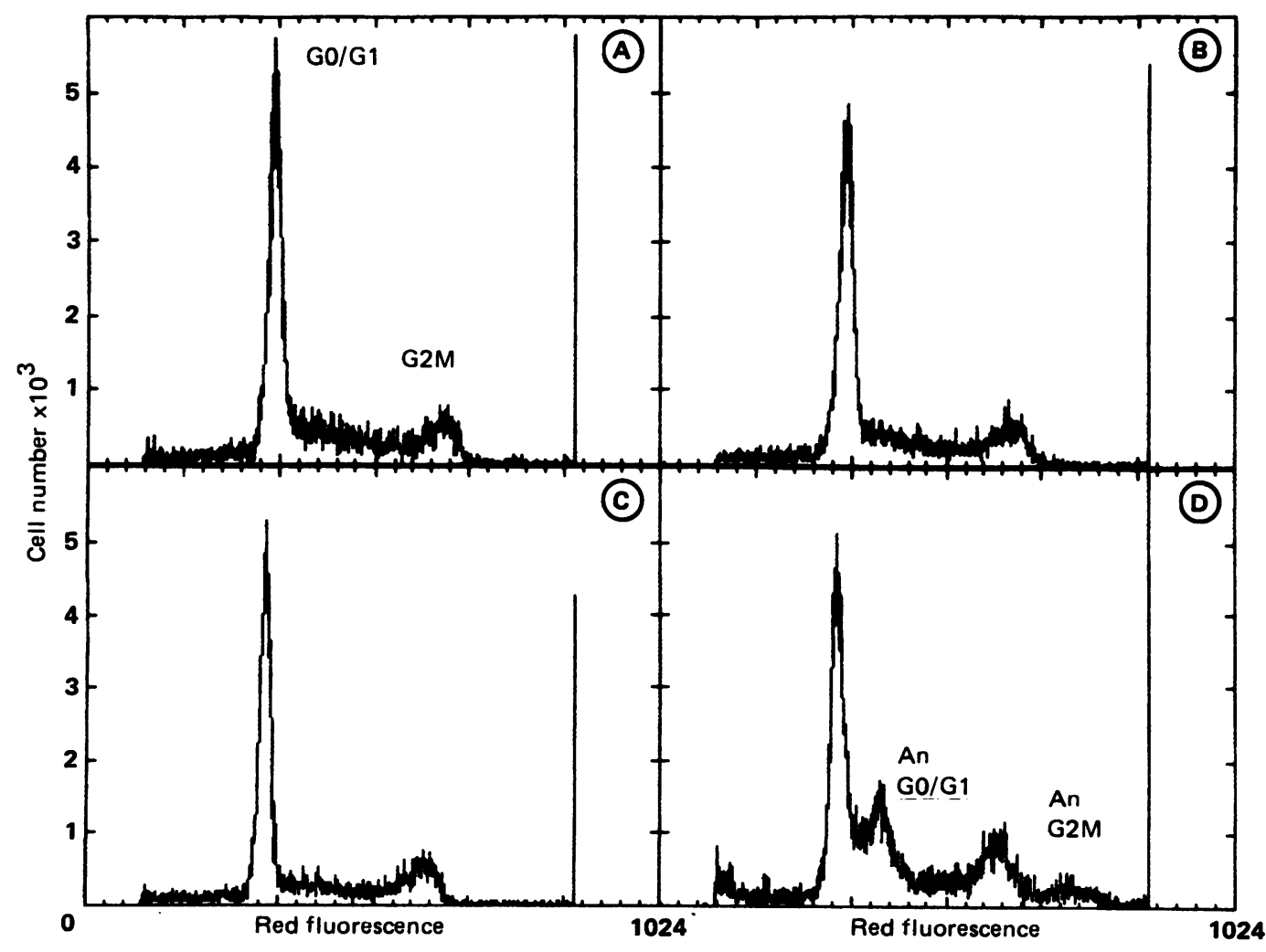


Figure 3 DNA histograms of Vero cultures: $(A)$ control cells; $(B)$ after incubation for 48 hours with $10 \mu \mathrm{g} / \mathrm{ml}$ spermidine showing $a$ hyperdiploid peak at An $G_{o} / G$ with $D N A$ index of $1 \cdot 19$.
Figure 4 Vero cells 48 hours after incubation with $10 \mu \mathrm{g} / \mathrm{ml}$ spermidine, stained with Rhodamine 123 and sorted into: $(A)$ non-viable $(2.49 \%$ viable cells); (B) viable cell population $(88.8 \%$ viable cells). The vertical line represents the cut-off point between viable and nonviable cells calculated on the basis of a background of autofluorescence. (C) DNA histogram of nonviable cells. (D) DNA histogram of viable cells showing hyperdiploid peak with DNA index of 1.15.

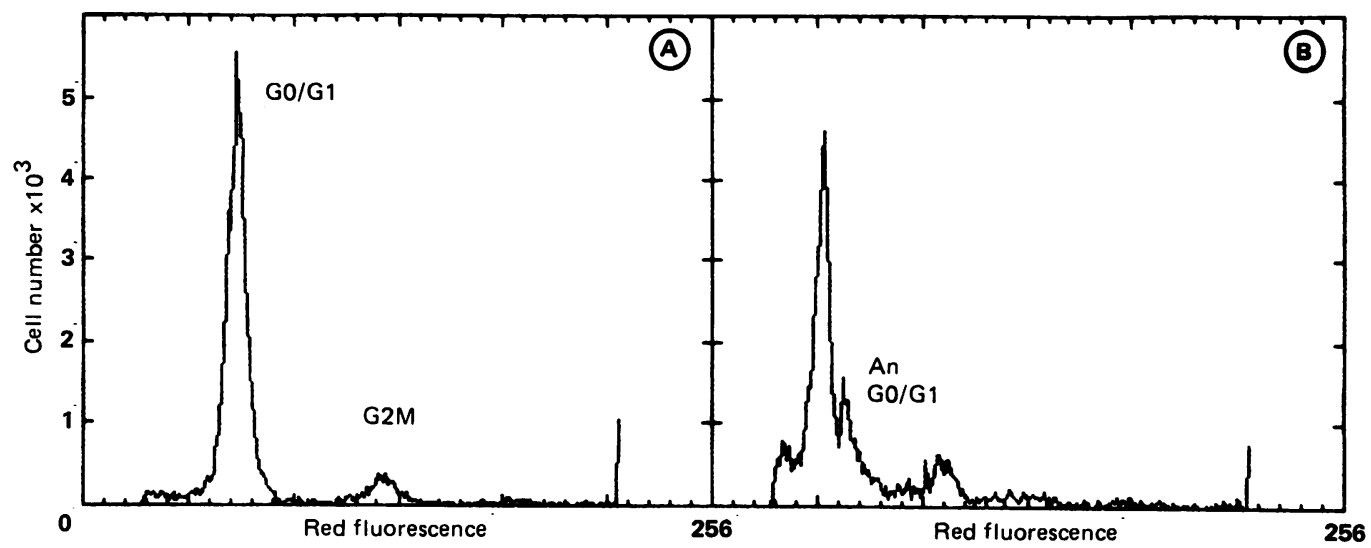

using the technique of Vindelov et al. ${ }^{11} \mathrm{~A}$ minimum of 10000 nuclei of each sample were analysed for DNA content after staining with propidium iodide. The flow cytometer used in this study was a Coulter EPICS C operating at a laser output of $150 \mathrm{~mW}$ at a wavelength of $488 \mathrm{~nm}$. Red fluorescent signals (RFL) were collected in linear mode on 256 or 1024 channel histograms. Analysis of cell cycle compartments was performed by the Coulter EASY-2 computer package incorporating "Cytologic" software.

\section{CELL SORTING}

Cells harvested by trypsinisation were pelleted by centrifugation at $500 \times g$ for five minutes and the pellets were resuspended in $100 \mu \mathrm{l}$ Rhodamine 123 (Sigma) at a concentration of $10 \mu \mathrm{g} / \mathrm{ml} .{ }^{12}$ Excess stain was removed by washing the cells in $0.01 \mathrm{M}$ phosphate buffered saline, $\mathrm{pH} 7 \cdot 2$. Cells were finally resuspended in medium containing $10 \%$ serum at $10^{6}$ per ml and sorted on the basis of the log green fluorescence (LGFL) signal collected on a one parameter histogram. Gates were set to collect viable and non-viable cells at a flow rate of 1000 cells per second. Both populations of cells were then processed for DNA analysis as above.

\section{Results}

\section{CELL LINES}

HeLa, CaSki, and SiHa cell lines were chosen for this study as they were all derived from cervical carcinomas and contain HPV sequences. HeLa has 10-50 integrated copies of HPV18 per cell with part of the genome from E2 to L2 missing. CaSki contains greater than 500 copies of HPV-16 per cell, all integrated, while $\mathrm{SiHa}$ has about 10 copies per cell of HPV-16, missing E2, E4, and some $\mathrm{L}$ sequences.

The three cell lines responded differently to the polyamines spermine and spermidine, used at concentrations of $0.4-50 \mu \mathrm{g} / \mathrm{ml}$. In the case of SiHa cells no changes in DNA profile were seen at any concentration at 24 hours, but at 48 the $G_{0} / G_{1}$ peak labelled An (aneuploid) (fig 1). hours a hypodiploid peak was observed below

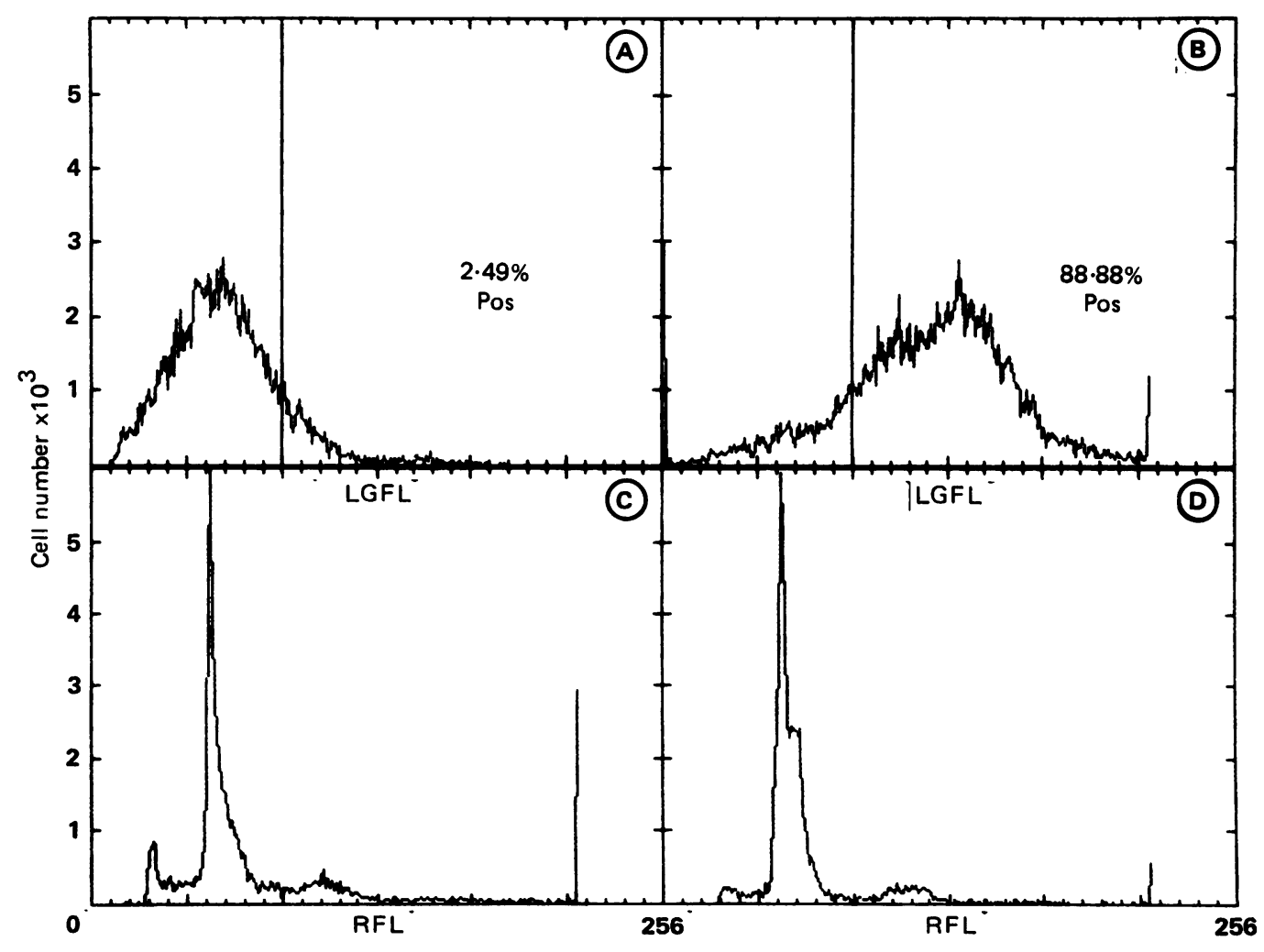




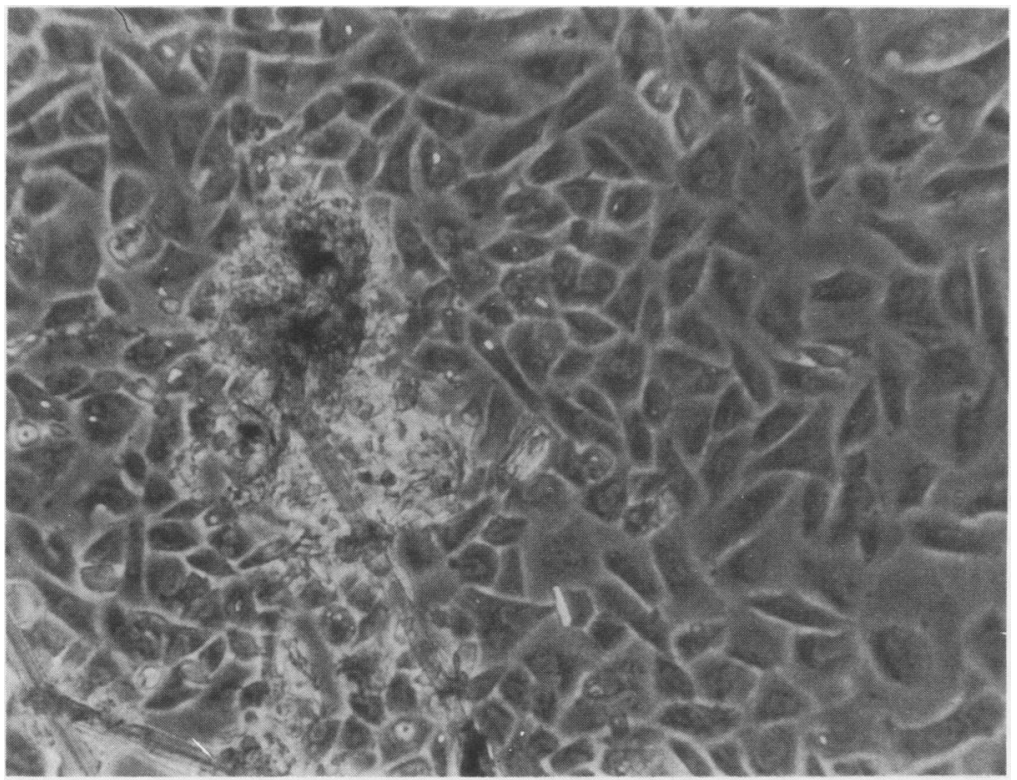

Figure 5 Cervical cells after 15 days in vitro showing epithelial outgrowth from an explant. on the basis of uptake of rhodamine by the mitochondria of viable cells. ${ }^{12}$ Non-viable cells exhibit a weak, diffuse, green immunofluorescence. The cells were therefore stained and separated into non-viable and viable populations (fig 4A and B). The DNA stain was then carried out on each population. Figure 4D shows that the DNA from the viable cell population contained the hyperdiploid peak (seen as a "step" on the descending limb of $\mathrm{G}_{0} /$ $\mathrm{G}_{1}$ ), while the DNA from the non-viable cells did not (fig 4C).

\section{CERVICAL CELLS}

Great care was taken to remove only the transformation zone of the hysterectomy specimens and 18 biopsy specimens were successfully cultured yielding squamous epithelial cell outgrowths, an example of which is shown in fig 5. The cultures were incubated in the presence of spermine, spermidine, or 1 , 3-propanediamine at concentrations ranging from $0 \cdot 2-50 \mu \mathrm{g} / \mathrm{ml}$, and the cell cycle analysed. There was no significant difference within the cell cycle compartments, even at the highest polyamine concentration (table). On occasion, however, both spermine and spermidine at $5 \mu \mathrm{g} / \mathrm{ml}$ or higher gave rise to histograms which exhibited aneuploidy with a DNA index of less than 1.0 (fig 6). These samples have been excluded from the table. The aneuploidy was found in two samples with spermine at $5 \mu \mathrm{g} / \mathrm{ml}$ and four at $50 \mu \mathrm{g} / \mathrm{ml}$, and in three samples with spermidine at $5 \mu \mathrm{g} / \mathrm{ml}$ and seven at $50 \mu \mathrm{g} / \mathrm{ml}$. Only some cultures showing aneuploidy at $5 \mu \mathrm{g} / \mathrm{ml}$ were also aneuploid at $50 \mu \mathrm{g} / \mathrm{ml}$. Aneuploidy was not seen with 1,3-propanediamine at any concentration.

For CaSki cells, no changes were seen hours, but at 48 hours a hyperdiploid peak with a DNA index greater than 1.0 was observed in cultures receiving $5 \mu \mathrm{g} / \mathrm{ml}$ spermine or spermidine, or greater. These changes persisted at 72 hours. A similar picture was found for $\mathrm{HeLa}$ cells except the paired hyperploid peaks were only seen at relatively high concentrations of polyamines $(25-50 \mu \mathrm{g} / \mathrm{ml})$. Analysis of the cell cycle compartments did not show any significant differences at the lower concentrations of polyamines. Examples of HeLa cells harvested at 48 hours are shown in fig 2 .

The hyperploid peaks were unexpected and further studies were done using Vero cells as these cells also showed a consistent hyperdiploid and hypertetraploid peak 48 hours after incubation with $10 \mu \mathrm{g} / \mathrm{ml}$ spermidine (fig $3 \mathrm{~A}$ and $B$ ). The Vero cell line is fibroblastic and derived from the kidney of a normal African green monkey. It was decided to separate the cell population into viable and non-viable cells

\section{Discussion}

Most studies on polyamines have concentrated on the effects of their depletion in cells using inhibitors affecting their synthetic pathways. DNA during the cell cycle of cervical cells when exogenous polyamines were present in the culture medium at or below the concentrations found in seminal fluid. The existence of a polyamine transport system has been shown in eukaryotic cells. ${ }^{13}$ Polyamines therefore accumulate intracellularly and are partially interconverted inside the cells.

Although the functions of polyamines in mammalian cells remain obscure, they seem to be essential for cell growth. ${ }^{5}$ The precise mechanisms of growth stimulation are difficult to define but include promoting or accelerating effects on all the major processes of proliferaWe wished to find out what happened to the

Proportion of nuclei in primary cervical cells in various phases of cell cycle after culturing with polyamines

\begin{tabular}{|c|c|c|c|c|}
\hline Polyamines & $\begin{array}{l}\text { Number of samples } \\
\text { suitable for } \\
\text { parametric analysis }\end{array}$ & $\begin{array}{l}\% \text { of nuclei in } \\
G_{0} / G, \text { phase (SD) }\end{array}$ & $\begin{array}{l}\% \text { of nuclei in } \\
S \text { phase (SD) }\end{array}$ & $\begin{array}{l}\% \text { of nuclei in } \\
G_{2} M \text { phase ( } S D \text { ) }\end{array}$ \\
\hline $\begin{array}{l}\text { None } \\
5 \mu \mathrm{g} / \mathrm{ml} \text { spermine } \\
50 \mu \mathrm{g} / \mathrm{ml} \text { spermine } \\
5 \mu \mathrm{g} / \mathrm{ml} \text { spermidine } \\
50 \mu \mathrm{g} / \mathrm{ml} \text { spermidine } \\
5 \mu \mathrm{g} / \mathrm{ml} 1,3 \text {-propanediamine } \\
50 \mu \mathrm{g} / \mathrm{ml} 1,3 \text {-propanediamine }\end{array}$ & $\begin{array}{r}18 \\
16 \\
11 \\
11 \\
8 \\
16 \\
16\end{array}$ & $\begin{array}{l}81 \cdot 8(10 \cdot 8) \\
82 \cdot 3(7 \cdot 1) \\
79 \cdot 1(8 \cdot 4) \\
78 \cdot 0(9 \cdot 5) \\
76 \cdot 5(10 \cdot 8) \\
83 \cdot 0(7 \cdot 3) \\
88 \cdot 5(6 \cdot 3)\end{array}$ & $\begin{array}{l}12 \cdot 4(8 \cdot 7) \\
11 \cdot 1(4 \cdot 6) \\
15 \cdot 7(6 \cdot 8) \\
17 \cdot 7(10 \cdot 3) \\
18 \cdot 1(9 \cdot 7) \\
12 \cdot 3(3 \cdot 9) \\
13 \cdot 1(4 \cdot 1)\end{array}$ & $\begin{array}{l}5 \cdot 4(2 \cdot 9) \\
4 \cdot 3(1 \cdot 9) \\
4 \cdot 8(2 \cdot 1) \\
4 \cdot 6(2 \cdot 0) \\
4 \cdot 4(1 \cdot 7) \\
3.9(1 \cdot 8) \\
6 \cdot 1(3 \cdot 6)\end{array}$ \\
\hline
\end{tabular}


Figure 6 DNA histograms of cervical cultures after incubation for six days with spermine at different concentrations (A) control cells; (B) 5 $\mu \mathrm{g} / \mathrm{ml}$ spermine; (C) 25 $\mu \mathrm{g} / \mathrm{ml}$ spermine; $(D) 50$ $\mu \mathrm{g} / \mathrm{ml}$ spermine; $B, C$, and $\mu g / m l$ spermine; $B, C$, and
$D$ show hypodiploid peaks (An) with DNA indices of $0.71,0.73$, and 0.79 , respectively.

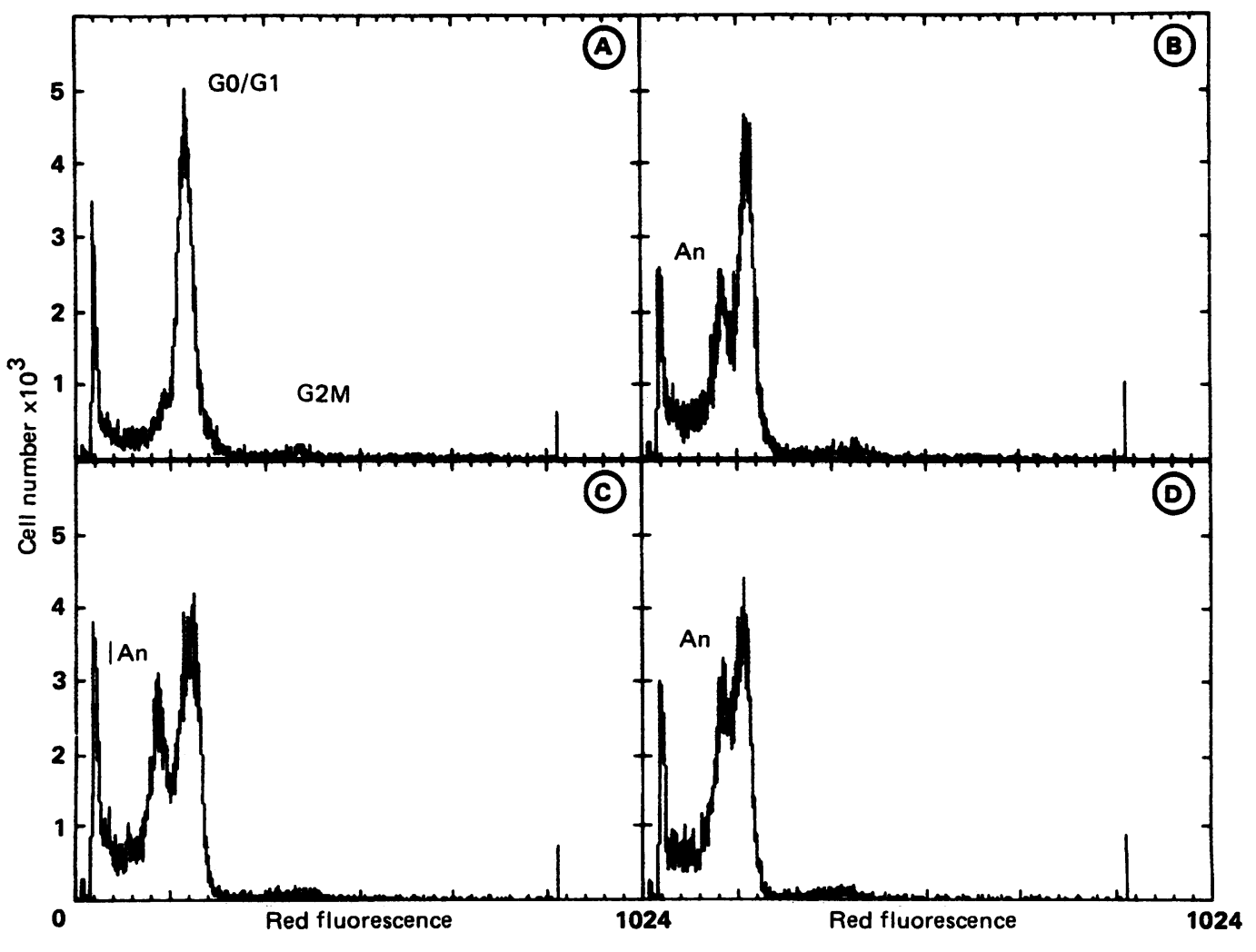

tion-DNA replication and transcription, mRNA translation, stability of mRNA and tRNA, and post-translational modification of proteins and enzymes. ${ }^{5}$ The growth effects of polyamines do not seem to stem from a restricted number of strong localised site-specific actions on enzymes (other than those for their synthesis and degradation), but from interactions of a much more general nature with a variety of macromolecules whose activities and relations they modulate. Of relevance to this study is the finding that in synchronised cells the intrinsic polyamine content is highest at the end of $G_{0} / G_{1}$ phase and has been shown to influence the initiation of DNA synthesis in the $S$ phase. ${ }^{1415}$

Polyamines are known to change the conformation of DNA by affecting its condensation ${ }^{16}$ and by inducing its transition from a righthanded helix to a left-handed helix in suitable base sequences. ${ }^{17}$ Manning has proposed that the polyamines are able to neutralise the negatively charged phosphate groups on DNA and, in high concentration, could cause collapse, condensation, or compaction of the DNA molecule by reducing their mutual repulsion. ${ }^{18}$ Others think that the polyamines may occupy the minor groove of DNA rather than cover the phosphate groups ${ }^{19}$ and there is also some evidence for site binding and intermolecular cross-linking, ${ }^{20}$ all of which would influence the access of transcriptional enzymes and the action of regulatory sequences.

In this study we have shown that exogenous spermine and spermidine in some instances can affect the DNA of primary cervical cells and cell lines. There was no evidence that the polyamines, even at high concentrations $(50 \mu \mathrm{g} / \mathrm{ml})$, were cytotoxic because the percentage of cells undergoing mitosis did not change.
Two unexpected effects, hypodiploidy and hyperdiploidy, were noted. These were not due to cell death as, in the case of hypodiploidy, an appropriate $\mathrm{G}_{2} \mathrm{M}$ peak was seen at a channel number twice that of the $G_{0} / G_{1}$ (figs 1 and 2), indicating that these cells are capable of division; in the case of hyperdiploidy cell sorting showed that the cells were viable. It is also possible that the polyamines had caused abnormal condensation of DNA in some cells, or perhaps had inhibited unwinding of the DNA helix, thus preventing the propidium iodide from intercalating and giving a false impression of the DNA content. Whatever the mechanism(s) it is clear that exogenous polyamines can change the structure of cellular DNA, and hence its function and regulation, and that they do so without loss of viability or mitotic potential. Thus the control of the cell may be sufficiently changed to predispose to dysplastic changes; further enhancement by other interacting factors, such as concurrent HPV infection, may be found. The protection afforded by cervical mucus is of obvious importance as it may prevent exogenous polyamines reaching the epithelial cell surface. On the other hand, high concentrations of nicotine ${ }^{2122}$ have been found in mucus and may well act as adjuvants to prevailing concentrations of endogenous and seminal polyamines. Changes in cervical mucus with puberty, menstruation, and oral contraception may also influence the protection afforded.

We are grateful to the Moray Endowment Fund of the University of Edinburgh for financial support and to Dr George Smart and Dr Jeremy Livingstone who provided the hysterectomy specimens. Dr Stewart Fletcher gratefully acknowledges the help and support of Professor CC Bird and the technical and secretarial staff of the Department of Pathology, University of Edinburgh. 
1 Kaufmann C, Ober KG. The morphological changes of the cervix uteri with age, and their significance in the early diagnosis of carcinoma. In: Wolstenhome GEW, O'Connor $\mathrm{M}$, eds. Diagnosis of early forms. London: J and A or M, eds. Diagnosis

2 Coppleson M, Reid B. Preclinical carcinoma of the cervix uteri. London: Pergamon Press, 1967.

3 Munoz N, Basch X, Kaldor JM. Does human papillomavirus cause cervical cancer? The state of the epidemiological evidence. Br J Cancer 1988;57:1-5.

4 McCance DJ. Human papillomavirus and cervical cancer. Lancet 1987; ;:986-7.

5 Tabor CW, Tabor H. Polyamines. Ann Rev Biochem 1984;53:749-90.

6 Mann T. The biochemistry of semen and of the male reproductive tract. 2nd Ed. London: Methuen, 1964.

7 Pegg AE. Recent advances in the biochemistry of polyamines in eukaryotes. Biochem $J$ 1986;234:249-62.

8 Prakash NJ, Schechter PJ, Grove J, Koch-Weser J. Effect of alpha difluoromethyl-ornithine, an enzyme-activated alpha difluoromethyl-ornithine, an enzyme-activated irreversible inhibitor of ornithine decarboxylase, on

9 Mamont PS, Duchesne M-C, Grove J, Bey P. Antiproliferative properties of DL alpha difluoromethylornithine in cultured cells. A consequence of the irreversible inhibition of ornithine decarboxylase. Biochem Bio phys Res Comm 1978;81:58-66.

10 Tabor $\mathrm{H}$, Tabor $\mathrm{CW}$. Biosynthesis and metabolism of $1,4-$ diaminobutane, spermidine, spermine and related amines. Adv Enzymol 1972;36:203-68.

11 Vindelov LL, Christensen IJ, Nissen NI. Standardisation of high resolution flow cytometric DNA analysis by the simultaneous use of chicken and trout red blood cells as internal reference standards. Cytometry 1983;3:328-31.

12 Darzynkiewicz Z, Traganos F, Staiano-Coico L, Kapuscinski J, Malamed MR. Interactions of rhodamine 123 with living cells studied by flow cytometry. Cancer Res
1982;42:799-806.

13 Fasulo L, Fulgosi B, Colombatto S, Grillo MA. Uptake of polyamines by human lymphocytes and their effect on polyamines by human lymphocytes and their effect on 1988;250:509-16.

14 Herbst EJ, Bronca AA. Polyamines, ODC antizyme and HeLa cell proliferation. In: Caldarera CM, Zappia V, Bachrach U, eds. Advances in polyamine research. Vol. 3. New York: Raven Press, 1981:287-97.

15 Boynton AL, Whitfield JF, Isaacs RJ. A possible involvement of polyamines in the initiation of DNA synthesis by human WI-38 and mouse BALB/3T 3 cells. $J$ Cell Physiol 1976;89:481-8.

16 Marquet R, Houssier C, Fredericq E. An electro-optical study of the mechanisms of DNA condensation induced by spermine. Biochim Biophys Acta 1985;825:365-74.

17 Behe M, Felsenfeld $G$. Effects of methylation on synthetic polynucleotide: the $B-Z$ transition in synthetic polynucleotide: the B-Z transition in PSA 1981;78:1619-23

18 Manning GS. The molecular theory of polyelectrolyte solutions with applications to the electrostatic properties of polynucleotides. $Q$ Rev Biophys 1978;11:179-246.

19 Zakrzewska K, Pullman B. Spermine-Nucleic acid interactions. A theoretical study. Biopolymers $1986 ; 25: 375-92$.

20 Allison SA, Herr JC, Schurr JM. Structure of viral PSI-29 DNA condensed by simple triamines. A light-scattering and electron-microscopy study. Biopolymers 1981;10: 469-88.

21 Sasson IM, Haley NJ, Hoffman D, Wynder EL, Hollberg D, Nilsson S. Cigarette smoking and neoplasia of the uterine cervix: smoking constituents in cervical mucus. $N$ Engl $J$ Med 1985;312:315-16.

22 Hollberg D, Nilsson S, Haley NJ, Hofmann D, Wynder E. Smoking and cervical intraepithelial neoplasia. Nicotine and cotinine in serum and cervical mucus in smokers and and cotinine in serum and cervical mucus in smokers 